\title{
Public Confidence in the Police: The Impact of Verbal Encounters
}

\author{
Kari Rønneberg \\ Bachelor Department, Norwegian Police University College, Oslo, Norway \\ Email: kari.ronneberg@phs.no \\ Received December $13^{\text {th }}, 2011$; revised January $8^{\text {th }}, 2012$; accepted January $16^{\text {th }}, 2012$
}

\begin{abstract}
The main part of ordinary police work consists of patrolling and answering calls, which means that most police officers are in a daily and direct contact with members of the public. During such encounters, especially if they take place by means of a telephone, language not only provides an important means to solve problems and exert social control, but it also helps to build relations, as well as to inspire confidence and trust. In this way, the communication process between police and the public provides the basis for police legitimacy and consequently, for successful police work. This article examines the impact of verbal communication between police officers and members of the public during day-to-day encounters, and shows how the linguistic and interactional choices of the police, e.g. when formulating a rejection or answering a request, may affect their relationship with the public in general, in positive as well as negative ways.
\end{abstract}

Keywords: Police Communication; Public Confidence; Service Encounters; Telephone Calls; Requests; Rejections

\section{Introduction}

In this article, my objective is to document the importance of the talk-in-interaction used by the police in their dealings with the general public, and how their choice of linguistic strategies may affect the communicative climate between the parties, for better or worse.

A consistent body of recent research links people's confidence in their police to specific, individual encounters with police officers, either by personal experiences or vicariously, through the knowledge of others' experiences (Skogan, 2009, 2006, 2005; Hinds, 2009; Rosenbaum et al., 2005; Weitzer \& Tuch, 2005). Some of these studies also clearly point to the importance of verbal communication. According to Tyler \& Huo (2002), a main concern when people consider the police and the courts are whether these authorities treat people fairly, recognize citizens' rights, treat people with dignity, and care about people's concerns (2002: p. 178). Weitzer \& Tuch (2005) link personal and vicarious experience with police misconduct with survey questions that also focuses on language use, e.g. "Have the police ever used insulting language toward you or toward anyone else in your household?" (2005: p. 287). As for people's negative experiences, the most important determinants of general dissatisfaction include "police being seemingly impolite, unhelpful, unfair, inattentive to what they had to say and unwilling to explain what was going on" (Skogan, 2006: p. 113). These findings are reinforced in Skogan (2009), in which bad experiences with the police are found to result from being treated "unfairly, unhelpfully and impolitely" (2009: p. 314).

Research also links successful police work to people's willingness to obey police regulations and decisions and to comply with the law in general (Tyler, 2006, 2004; Rosenbaum, Schuck, Costello, Hawkins, \& Ring, 2005; Tyler \& Huo, 2002). This means that the communicative meeting which takes place between police and ordinary citizens can be defined as an investment in good relations, in the way that it builds confidence and willingness on the part of the public to cooperate with the enforcers of the law. On the other hand, if this is not the case and the communication between police and the public is unsuccessful, such encounters may lead to mutual distrust, which in turn may bar any future attempt at building relations between the two parties. Research also shows that it is the negative experiences which affect people's attitudes to the police the most, and also that this is particularly notable when it is the members of the public who take the initiative to the encounter (Skogan, 2006).

Language, thus, is a core element in all such meetings between the public and the police. In spite of this, however, the talk-in-interaction between the police and the public in their day-to-day encounters has seldom been the focus of extensive linguistic research. What has been studied has mostly been police language in structured and goal-oriented situations, such as police interviews and calls to emergency centers, cf. Jönsson, (1988); Jönsson \& Linell, (1996); Whalen \& Zimmerman, (1987); Manning, (1988); Whalen \& Zimmerman, (1990) and Zimmerman, (1992). However, both Jönsson's (1988) and Riis-Johansen's (2005) studies of police interviews also show how the police use informal everyday language as a tool in order to create a friendly and relaxed atmosphere. The latter describes this use of informal language as a deliberate strategy, to reduce the impression of asymmetry, because "to do their job, the officers depend on a good relationship with the suspect" (2005: p. 95).

An interesting study in this respect is Couper-Kuhlen's (2007) analysis of displayed affect in interaction. Displayed disappointment after a rejection, signalled e.g. by a subdued tone, is usually followed by signs that the disappointment has been registered and by explanations or attempts at comforting the other. However, stronger expressions of affect, such as surprise or irritation, usually also accompanied by a reformulated request, will only get a repeated rejection as a response. Repeated rejections as the only answer can in turn lead to a less harmo- 
nious climate, in particular if the rejection-giver feels that his or her authority is being questioned by the other's non-accept, and especially when the rejection is followed by arguments, sometimes also in an aggressive tone. Such a tone may be construed as a challenge, an inappropriate thing to do, and consequently, the rejection-giver may choose to answer in the same note, which can bring conflict about (see also Rönneberg \& Svennevig, 2010: p. 301).

\section{Data and Sample}

The data used in this article are all taken from an empirical study of citizen-initiated telephone calls to the police. The corpus consists of a total of 900 telephone conversations, or excerpts of conversations, recorded at the 24-hour duty desk of an Oslo police station during two different periods of time during 2002 and 2003. While the total number of recordings is about 1500 , approximately half of these are calls from the public to the police. These have been categorized into three more or less distinct groups. The largest category, between 700 and 750 calls, can typically be described as routine calls, in the sense that they deal with often recurring themes, that they follow more or less standard procedures, and that their outcome is fairly predictable. The second group, less numerous, consists of approximately 100 calls that touch upon institutional constraints, thus making positive answers difficult to give, a fact which also ensures a certain degree of predictability. The third group of calls, approximately 50, are those which are problematic in some way or another, either because of a poorly organized message, because of mentally unbalanced or emotionally disturbed callers, or because circumstances are complex or diffuse, all of which contribute to an unpredictable outcome. From the above categories, a representative sample of 190 excerpts has been selected and then transcribed and analyzed according to the principles of Conversation Analysis (CA). For further reading, see Rönneberg (2009) \& Rönneberg (2011).

\section{The Service Encounter as a Communicative Ge- nre}

Witness and suspect interviews as well as emergency calls for assistance represent two main communicative activities in the interaction between the police and the public. However, both differ from the everyday encounter between police and the public by their distinctly task-related and goal-oriented character, within specific and restricted domains.

Police interviews or questioning of witnesses or suspects (in the latter case, sometimes called interrogations) focus on committed offenses with the sole objective of gathering as much and as correct information as possible about the events. Emergency calls provide the call-taker with a dichotomous task while pressed for time, having to decide whether the caller is entitled to help or not. Compared with the above activities, the day-to-day verbal encounter between police officers and ordinary citizens, in the study represented by telephone calls to a police duty desk, present the call-taker with far more diversified tasks, with a goal-orientation which is not always very specific.

As a communicative event, this service encounter has in fact a double objective. On the one hand, a broad specter of calls have to be correctly responded to, from requests for information, advice and assistance, to reports about anything ranging from minor incidents to observations of accidents, suspicious events and committed offenses. At the same time, the interaction should also contribute to a trusting and harmonious relationship between the public and the police, whether it takes place as a face-to-face encounter or by means of a telephone. During such encounters, language not only provides an important means to solve problems and exert social control, but it can also build relations and inspire confidence and trust. The latter is of the utmost importance, since the police depend on the public for information, co-operation and support. Also, a stated objective of the Norwegian Police Directorate in their Strategic plan for 2006-2009 is that "The public's encounter with the police should be positive". During such verbal meetings, then, the spoken language will provide the link between the police officer and the citizen, and as such, either serve as a tool to build relations and inspire confidence, or, on the other hand, create distance and possible distrust. The latter is of particular importance, since research shows that the impact of having a bad experience with the police is four to fourteen times as great as that of having a positive experience (Skogan, 2006).

The analysis of my own data shows that a distinctive general feature, common to the majority of the calls, and observable from the very first sequence of the calls, is the mundane and informal character of the police officers' language, which also leaves room for humour, empathy and occasional small-talk. While such characteristics are not usually expected in institutional conversations in a formal setting, here the effect is to contribute to a relaxed and informal atmosphere which reduces the formality of the situation, and opens for "exchange relations" rather than "power relations" (Linell, 1990). The informality also reduces the asymmetry between what is everyday routine for the professional, and a unique and special occasion for the caller (Drew \& Heritage, 1992).

A characteristic feature is the consistent use of politeness strategies, such as the general use in routine situations of positive politeness, which is the politeness strategy used when disappointment is to be expected, typically when answering often-recurring requests about lost property, which more often than not are given negative replies. Equally consistent is the use of negative politeness when people are requested to perform acts that infringe upon their personal liberty, and when a careful approach is needed to mitigate the threat to their freedom of action (Brown \& Levinson, 1987). An example is how the police inform about the need to make a personal appearance at a police station in order to make a formal report about an offense, in spite of the time it usually takes to wait in line at the desk. In this way, the language in itself becomes a means to maintain harmony in the interaction, and to prevent disagreement from turning into discontent or aggression.

As in the following excerpt, an answer to a caller who has called about lost property:

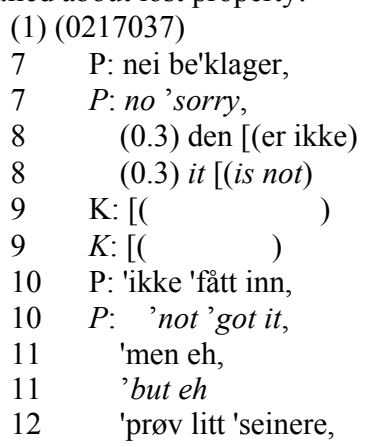




\section{K. RØNNEBERG}

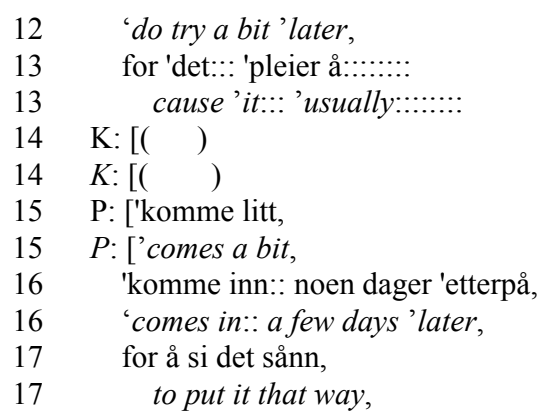

As we observe, the negative message is packaged into a series of dispreference markers, which are politeness mechanisms that signal a call-taker eager to minimize the recipient's expected disappointment. The first "no" is accompanied by an expression of regret, which is followed by a restart and a hesitating "eh" before the negative answer is given in line 10 . Then follows some encouraging advice ("do try a bit later"), accompanied by an explanation ("it usually comes in a bit later"), modified by drawn-out sounds, until a final modifying "to put it that way", so as to warn against too much optimism.

The next excerpt is taken from a conversation in which a distraught mother, who has just been told that her nineteen-yearold son who has been missing all night, is with the police. Because of professional secrecy, however, the police officer are unable to tell her why, since in Norwegian law a person above 18 is "of full age and legal capacity". Thus, no account can be given to the worried mother who wants to know what has happened:

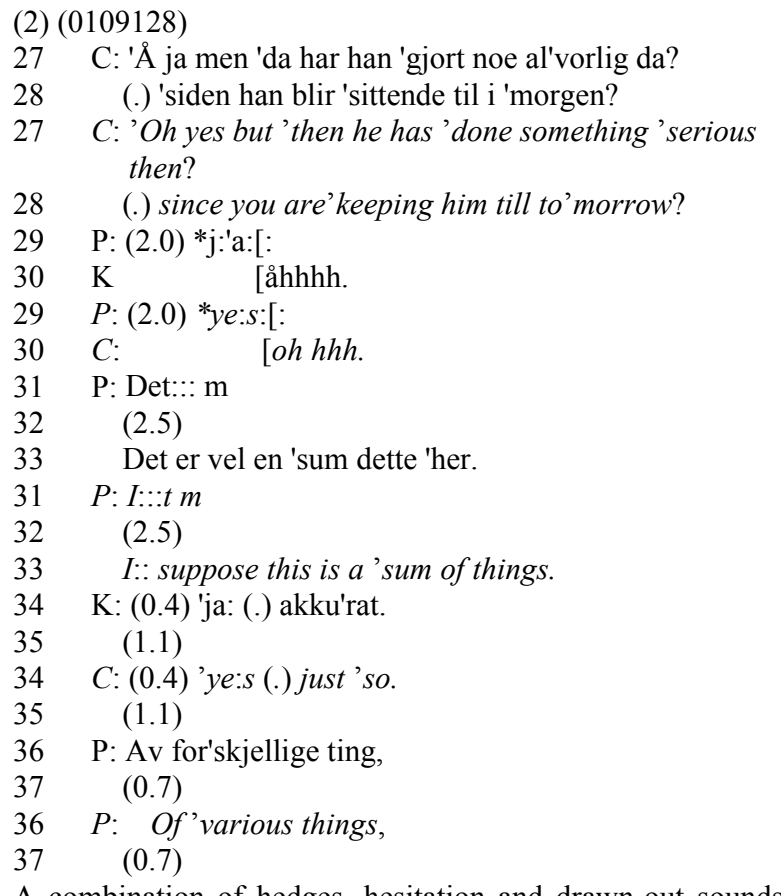

A combination of hedges, hesitation and drawn-out sounds are all signs of the officer's attempts at taking the sting out of the bad news that is conveyed by his non-responses. However, the silence in line 29, before the officer's hesitating "yes", as well as the long pauses in lines 32 and 35 , tell as clearly as words that something is wrong. Towards the end of the conversation, we also find empathy displayed in the format of the response:

(3) (0109128)
71 P: > Det 'er det $<$ 'det er 'der dess'verre det 'beste jeg får 'gjort for deg,

$71 P:>$ It' $i s$ it $<$ 'it is 'there re'grettably the 'best I can 'do for you, alt $[$ så.

72 you [see. nisms, combined with the everyday, informal character of the language, is to convey a tone of consideration and respect, while also alleviating the relative formality of the situation. This in turn contributes to an impression of symmetry and "asif-equality" (Luckmann, 1990) between the professional and the layperson, which encourages closeness and personal contact between the two, thus facilitating the communication process.

In another excerpt, the caller complains about not having got a reply to a letter in which he has reported a burglary in his office, which he needs for reasons of insurance. He wants to know why he still has got no formal reply from the police, and whether his report has been registered. The duty officer has tried to locate his letter, without success. She then suggests that best thing for him to do is to show up in person at a police station to report the matter once again. Her argument is that this will save time, he will get his document while he is there, the same day.

(4) (0110011)

36 P: nei vi syns at eh det at du 'nesten må 'møte opp per'sonlig her, No what we suggest eh is that you should 'rather come' down here in 'person,

37 (0.2) men eh som $\mathrm{s}$ *det er 'veldig stor eh:[:: $(0.2)$ but eh as ${ }^{*}$ there are quite a lot eh:[::

$38 \mathrm{~K}:$

$39>$ det er helt $<$ 'meningsløst, $>$ it is totally< ab'surd,

$40 \quad \mathrm{i}$ 'min i og med at det 'e:r :::eh hh .hhh In 'my since it' is :::eh hh .hh

41 P: men (alt 「 ) But (all [ )

42 K: $\quad$ ja jeg 'hakke !tid til det for å si det 'kort og 'godt og::: og:: !dere, [yes the' short of it is I'haven't got the !time for this and::: and :: !you,
(som) >det hadde vært 'innbrudd 'her $<$ jeg 'ringt til dere, (as) > there had been a 'burglary' here $<$ I'called you,

44 dere hadde ikke 'tid til å komme !hit, You did not have 'time to come! here, $45 \quad . h h h\lceil(\quad)$

After several attempts by the police officer to placate the angry caller, by informing him about police procedures and also by suggesting possible alternatives, the caller finally realizes that unless he turns up in person at the police station, he may have to wait a couple of weeks more for the papers he needs for the insurance. His temper rises once again:

$93 \mathrm{~K}$ : $\quad$ så det blir liksom mye,

So I mean this is really too much,

95 P: $\quad$ ja,

$96 \mathrm{~K}: \quad$ formaliteter som $\lceil($ )

Here, the police officer changes her tone and also her strategy, concentrating on promoting the services the police station 
is able to render:

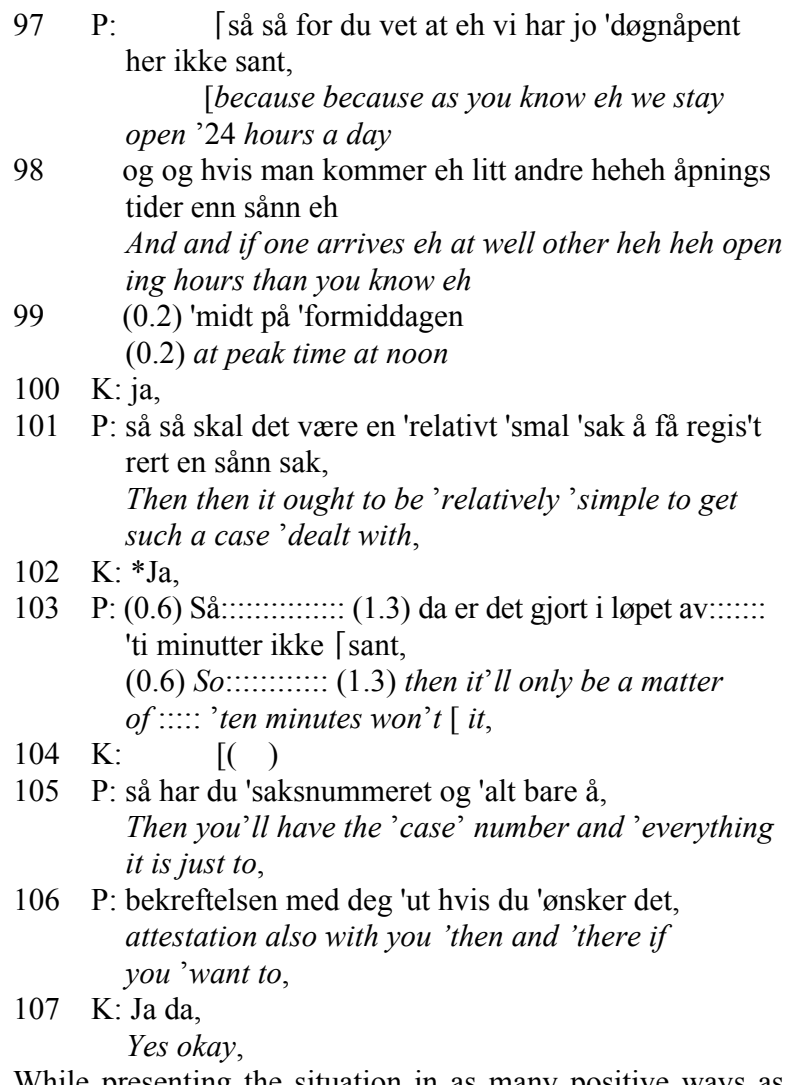

While presenting the situation in as many positive ways as possible, the officer also underlines her understanding of the situation by linguistic devices such as drawn-out sounds, hesitation, laughter and encouraging small talk, and also adding "if you want to" in the end, to underline that the choice is his. This changes the tone of the call, and the caller accepts with a "yes okay". However, the conversation is far from over, because the caller now recalls another encounter with the police, namely when he had to report a stolen car, and what he now clearly remembers is having to wait for a long time at the desk:

$173 \mathrm{~K}$ : * ja eh da jeg da jeg 'var her med denne 'bilen eh så 'satt jeg der i 'timesvis,

*yes eh when I'was there on account of this' car eh I had to 'sit there for 'hours,

175 nei det blir håp 「løst. No that is hope[less

176 $\mathrm{K}: \quad$ da eh blir det sånn,
$\quad$ [then eh it becomes sort of

177 P: (0.7) Så det $\lceil::$ So that $[:$ :

178 K: $\quad$ da blir det sånn 'litt for 'mye 'tid, [then it becomes sort of a'bit too 'much 'time,

179 P: jada, Yes of course

180 det skal du ha full forståelse for,

There is every reason to agree with you there,

181 men eh::.:.:: litt 'utenom eh 'vanlige sånn rushtider så:::,

But eh:::::: a bit outside of eh the 'usual kind

of'rush hours then :::,
182 så pleier det å gå 'relativt 'kjapt, It usually goes relatively' fast,

$183 \mathrm{~K}$ : .hhh Yes nei men da 'ser jeg om jeg 'hører no 'fra dere hvis 'ikke .hhh Yes no but in that case I'll'see if I'hear from you if' $n o t$

184 så får jeg ta jeg meg en tur bort, I'll drop by some time tomorrow,

185 sånn en eller annen eh::: 'tid i morgen. Sort of some time or other eh::: 'time tomorrow.

As we see, the police officer has chosen the tactique of agreeing totally with his complaints, instead of trying to defend the routine of the police station. This results in a happy customer who has no problems with accepting his fate, which is to "drop by" at the police station "some time tomorrow". All his counter-arguments have vanished, in his meeting with this very understanding police officer.

\section{When the Rule of Politeness Does Not Apply}

As stated above, in the overall majority of the conversations, politeness strategies are the rule. This is particularly notable when often-occurring service requests or repeated reports about the same kind of day-to-day nuisances have to be answered in the negative. Even when answering the very common inquires about lost property, the officers almost without exception "package" their negative replies in politeness mechanisms, such as pre-sequences and reservations, hedges, accounts, regrets and expressed empathy, all of which contribute to alleviate the caller's foreseeable disappointment, as shown in example 1 above.

Since displayed courtesy and respect by the police officers seem to be regular procedure in calls belonging to the "routine" category, one would assume to find the same consistent use of politeness mechanisms within the two other and less numerous categories, especially in calls that touch upon institutional constraints. In such cases, a negative answer will often be impossible to avoid, and so a dispreferred format, characterized by all sorts of face-saving devices, is what you would expect, whether the rejection might be due to reasons of confidentiality, the station's internal priorities, a lack of resources or simply, because the caller's errand is not judged to be police relevant. An interesting finding is that while negative or unwanted answers are almost always given in a thoroughly polite form in the case of the routine requests, it is precisely within the category of calls which concern institutional constraints that we find the exceptions to the rule. As in the following example, in which the caller wants the help of the police to have his lost mobile phone blocked, a request that probably does not qualify as a police matter and is consequently rejected. However, the caller has explained his reasons for calling, which is that he is unable to reach the company in charge, since nobody answers his call.

(5) (0302009)

20 K: (0.3) og: 'det er bare 'det .hhh heh hh.

$20 C:(0.3)$ an:d 'it is just' that . hhh heh hh.

21 så: jeg 'vet ikke om du kan hjelpe meg med 'det eller 'ikke,

21 so: I don't 'know if you can help me with 'this or 'not,

22 for å få det 'sperra,

23 (1.4)

22 to have it 'blocked. 
23

(1.4)

The format of the request may possibly indicate that the caller himself is aware that he is asking for something that is potentially irrelevant, by the fact that he adds "or not" (line 21). However, the somewhat unusual wording may perhaps be due to the fact that the caller has a non-Norwegian background, which is suggested by his accent, as well as by the way the words are accentuated.

The long silence which follows suggests that something is the matter. The response, when it comes, is given directly and without any account:

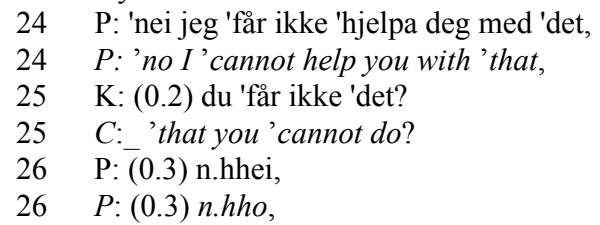

The caller's reacts to the answer by repeating it (line 25), thus displaying surprise, which may be caused both by the rejection and its direct format. However, it may also be initiating repair. Which is not given, the rejection is simply confirmed by "no". This is followed by yet a repetition, this time suggesting disbelief:

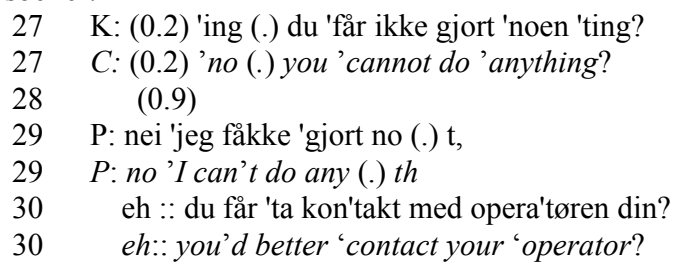

A possible explanation for the lack of politeness mechanisms in this case may simply be that the officer sees no need for service-mindedness as long as the caller's request is not a matter for the police. However, when looking more closely at other calls belonging to the same category of institutional constraints, we find that quite a few responses are given in a direct and rather blunt way, where you would expect the same politeness strategies that seem to be the rule in the more standard conversations.

Of course, one reason why requests that concern confidential matters sometimes are given in a direct format is that it may be hard to provide an answer, and at the same time, not saying too much. What we do find, however, is that in some of these calls, the problem of not being able to answer is partly solved by the officer's account of why this is so. As in the following example:

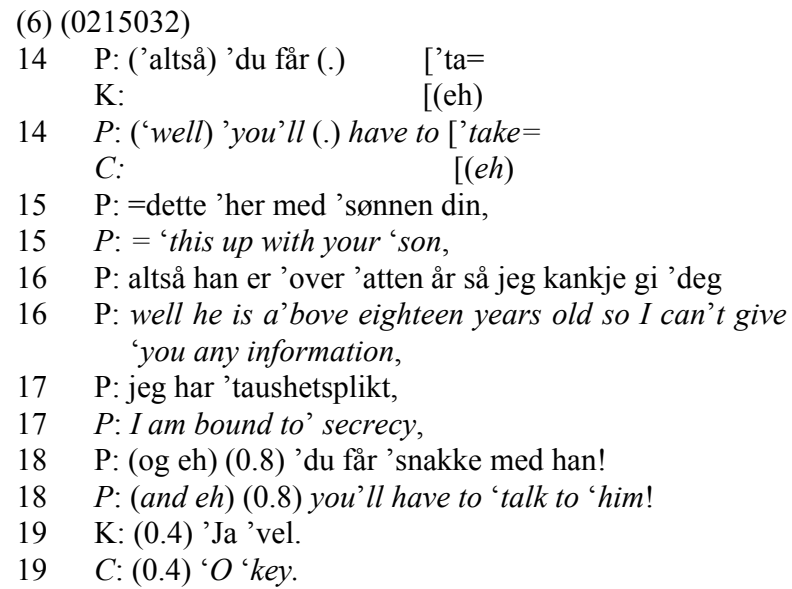

$20 P:($.$) ' \mathrm{mhm}$,

20 P: (.) 'mhm,

Still, it is not unusual to find rejections of requests concerning confidential information being delivered directly, and also without an account, which might have mitigated the abruptness of the response:

(7) $(0302025)$

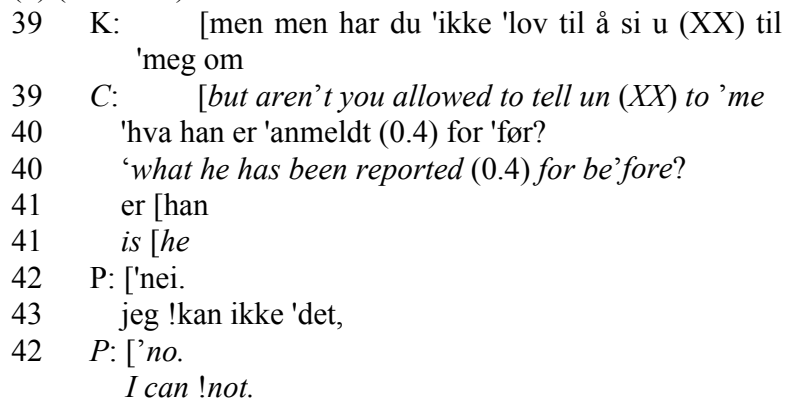

A woman who has inquired about her husband's whereabouts, has been told that "the police have talked with him today". She then goes on to ask for details:

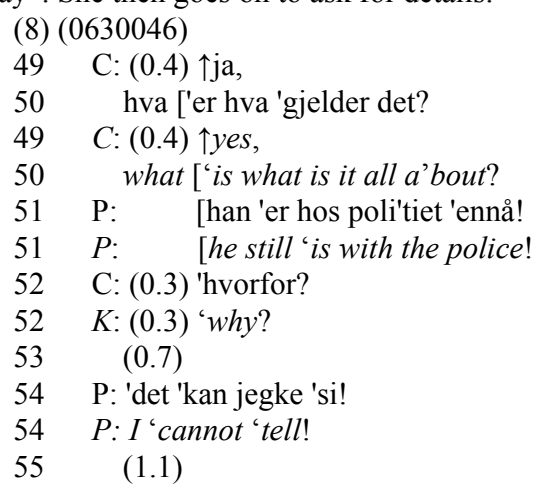

In another example, a woman calls about a stolen handbag belonging to a friend, which contained a lot of valuables, including wallet, mobile phone and various bank cards - "all her valuables" is how she describes it. Why she calls is not to report the loss, which has already been done, but to convey an important message, namely that when they call the number of the stolen phone, somebody answers it. What she then expects the police to do is to immediately trace the phone, and in this way catch the wrong-doers.

The police officer's response is clearly negative from the very beginning of the call. When he declares that it is impossible to trace a mobile in the way she expects the police to be able to do, she hardly believes him. Her disappointment takes the shape of a challenge:

(9) (0302015)

127 K: og 'mer 'klarer ikke 'dere å 'finni ut?

$127 \mathrm{C}$ : and 'that is 'all 'you are 'able to 'do?

$128 \quad(0.6)$

This is a clear confrontation, in a direct and personal form, addressing the other directly, and with a stress on syllables such as "able to". She possible attacks to save her own face; instead of accepting to have asked a silly question, she implies that it is the police who are not doing their job.

The officer picks up the glove. Here it is his position of power which is threatened. What he does is to respond from his status position as an expert:

129 P: nei ikkje !sånne saker hadde det 'vært en 'drapssak

$129 P$ : no not ! that kind of cases if had it 'been a 'murder 


\section{K. RØNNEBERG}

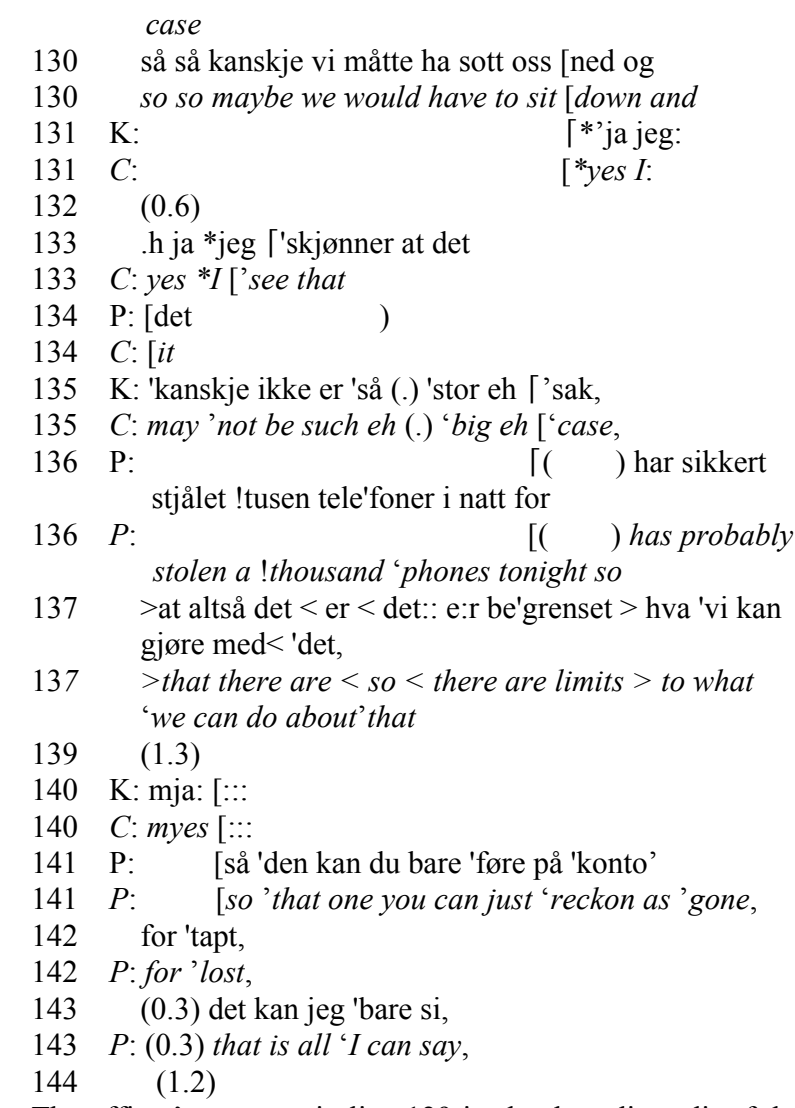

The officer's answers in line 129 is clearly a discredit of the importance of the case, and consequently of her poor judgement as well. In this way, he also threatens her positive face. What he implies is that her errand - and by this, herself-are of no importance, seen from a police perspective. Not only does the case belong to the category of "! that kind of cases", but it also marks the contrast with the other and far more serious kind of cases, namely murders.

However, we also notice a change in the voice of the caller. She has lost her self-confidence and become hesitating (line 135). Her response is given in a creaky voice and as a hesitating admittance: her important information is not so important after all. When the call comes to an end some twenty lines later, it is probable that what the caller will remember is an impression of a police force that lacks both the will and the ability to help a person who has lost "all her valuables". Such a loss of confidence will take time to rebuild, if it is not too late already, and, what may be worse, the sad story about a non-cooperative police is sure to be spread to all her acquaintances and thus heighten the negative effect.

\section{Discussion}

The verbal encounter between the police and the public as presented in these examples show how the linguistic strategies of the police can directly affect their relationship with the public. In examples (2) and (3), we see that the use of politeness mechanisms (drawn-out sounds, hedges) and the use of a relative informal language help alleviating a situation which to the member of the public may be felt as rather threatening (her son is with the police for some unknown misdoings). The overall effect caused by the officer's choice of linguistic strategies is a tone of closeness and personal contact between the two.

In example (6), we see how the officer solves the similar problem of not being able to answer a request concerning confidentiality by providing a rather long explanation of why he is unable to answer. That this partly solves the caller's problem is shown in his acceptance of the account by a finalizing "okay", indicating that the officer's strategy may have affected their relationship in a positive way. In examples (7) and (8) which also concern questions of confidentiality, direct rejections are given without any attempt at providing explanations, a fact that we may assume is not perceived by the callers as contributing to a positive relationship.

Another example (4) shows how the officer's choice of strategy, here agreeing totally with the customer's complaints instead of trying the defend the police routines, changes the whole tone of the interaction. From dealing with a rather grumpy caller with numerous complaints, the police officer's tactique ensures that in the end the other rather happily accepts what he initially did not want to, namely to turn up in person at the police station to file a complaint for the second time.

In example (5) we notice a different kind of impact resulting from the officer's rather blunt rejection of the caller's request for help. The caller's perception of the situation is shown first by his expressed surprise, followed by an expression of disbelief at the direct rejection. His reactions clearly suggest a relationship that is affected in a negative way.

In the last example (9) a confrontation follows from the officer's negative handling of the caller's request, namely that the police should be able to trace a stolen mobile phone and thus clear up a robbery in which several valuables have been stolen from the caller's friend. The officer's negative response provokes the other into answering back on the same tone, which starts a full-fledged argument between the two. Here, the officer ends up as the winner, discrediting the importance of her case and thus threatening her judgment and consequently her positive face. The result is a loss of self-confidence on the part of the caller, and also, we may assume, a loss of her former confidence in the police.

The examples thus show how the linguistic and interactional choices of the police may clearly affect the relationship between police and the public, in positive as well as negative ways.

As we notice in some of the examples above, belonging to the category of institutional constraints, the officers' rejections of the callers's requests are sometimes given in a direct and unmitigated form, which, as already stated, contrasts with the otherwise consistent use of dispreference mechanisms which characterizes negative answers given in the much larger "routine" category of calls. When comparing the various categories and the ratio of negative answers in each, it appeared that within the large so-called "routine" category I hardly found any example of lack of politeness mechanisms or affective response at all. In the less numerous category of institutional constraints, however, a fairly large number of calls showed examples of lacking mitigating devices were lacking. When comparing 32 excerpts from this category, in 24 of them the rejection was given directly, without any politeness device to soften the answer. In a full eight of them, thus one third of the sample, there was no account that might have explained why the rejection was given. In only four of them I found a "sorry" or "I regret".

A possible explanation why certain calls are dealt with in a way that may cause frustration and heighten the conflict level, 
may be found in the officers' perception of their own role as police. While many seem to see themselves as advisors and problem-solvers, others seem primarily to be in the role as enforcers of law and order. Where some are attentive to citizens' personal problems as well, others restrict their dealings with the public to the factual and professional.

At the same time, the police may also perceive the role of the public in various ways. As the examples show, most calls are dealt with in a polite and respectful way, especially in routine requests, such as calls about lost property or misparked cars. On the other hand, when the callers' questions touch upon institutional constraints, or when help is requested with matters which are not seen as "police business", the norms of politeness do not always apply. There are also examples of rejections which seem to indicate that some citizens - or groups of citizens - are met with less respect and consideration than others. Obviously, there seem to be certain norms at work, or some implicit standards that influence the way the members of the public are dealt with, and also whether they seem entitled to assistance or not.

Another source of conflict may be unclear perceptions of what police work is really all about. As some examples seem to indicate, what is or is not a "matter for the police" may depend more on the police's own perspective on what "real" police work consists of, and less on how the citizens define their own needs. However, according to a recent Norwegian Parliamentary "White Paper" defining the role and tasks of the police, it is clearly stated that "the safety of the individual citizen and society at large" should be a primary objective for the police in their work, and also that the public should be given a "swift response when help is needed". Added to this, it is made clear that the concept of "safety" should be understood from a citizen perspective and people's own perceptions of "their need for help".

\section{Some Concluding Remarks}

A general observation is that in police interaction with the public, lexical choice and linguistic design may be just as important as what is actually said. A thoroughly polite and respectful way of dealing with the callers, even in routine matters, contributes to establishing and maintaining a harmonious relationship with the public at large. This is of particular importance in the case of refusals, where the use of politeness strategies can have a decisive effect on how the answer is understood, and whether the rejection is accepted or becomes a source of frustration, arguments and ensuing conflict.

Also, when problems occur, they seem to arise not so much from what is actually said during the interaction, as from what is not said, e.g. by not answering questions, by not taking the expected turn at a transition-relevant place, by not repairing obvious signs of trouble in the conversation or by not providing accounts.

In a wider context, the abrupt tone of some of the refusals may also reflect a tendency to sort citizens' requests into categories according to the importance of the reported trouble, which again may lead to less attention being accorded to minor offenses such as burglaries, thefts, threats and harassment than to the more serious, however far less common, crimes such as killings, armed robberies and trouble with criminal gangs. However, it is the common offenses, often referred to as "everyday" crime, that most people are bothered with, and for which they ask for police assistance. If such requests are turned down, sometimes also in a direct, unmitigated way, the consequence may be a loss of confidence in the police, and also in their willingness and capability to provide the kind of help with what the public consider to be their real problems.

\section{REFERENCES}

Brown, P., \& Levinson, S. C. (1987). Politeness: Some universals in language usage. Cambridge: University Press.

Couper-Kuhlen, E. (2009). A sequential approach to affect: The case of “disappointment". In M. Haakana, M. Laakso, \& J. Lindström, (Eds.), Talk in interaction - Comparative dimensions (pp. 94-123). Helsinki: Finnish Literature Society (SKS).

Hinds, L. (2009). Public satisfaction with police: The influence of general attitudes and police-citizen encounters. International Journal of Police Science and Management, 11, 54-65. doi:10.1350/ijps.2009.11.1.109

Jönsson, L. (1988). The police interview as communicative situation. Linköping: Linköping University.

Jönsson, L., \& Linell, P. (1996). Misbelief sequences in police interviews. In: M. Thelander et al. (Eds), Samspel och variation: Språkliga studier tillägnade Bengt Nordberg på 60-årsdagen (pp. 199-208). Uppsala: Uppsala University.

Luckmann, T. (1990). Social communication, dialogue and conversation. In I. Markovà, \& K. Foppa (Eds.), The dynamics of dialogue (pp. 45-59). New York: Harvester Wheatsheaf.

Manning, P. K. (1988.) Symbolic communication. Signifying calls and the police response. Cambridge, Massachussetts: MIT Press.

Riis-Johansen, M. O. (2005). The police interview as conversation. Trondheim: Hovedoppgave i anvendt språkvitenskap. Institutt for språk-og kommunikasjonsstudier, NTNU.

Rosenbaum, D. P. et al. (2005). Attitudes toward the police: The effects of direct and vicarious experience. Police Quarterly, 8, 343-365. doi: $10.1177 / 1098611104271085$

Rönneberg, K. (2009). Police conversations with the public. Linguistic features which may help or hamper the communication process. Acta Humaniora No. 378, Oslo: University of Oslo.

Rönneberg, K. (2011). Police Conversations with the Public. Linguistic features which may help or hamper the communication process. Unipub.

Rönneberg, K., \& Svennevig, J. (2010). Declining to help: Rejections in service requests to the police. Discourse \& Communication, 4, 279-305.

Skogan, W. G. (2005). Citizen satisfaction with police encounters. Police Quarterly, 8, 298-321. doi:10.1177/1098611104271086

Skogan, W. G. (2006). Asymmetry in the impact of encounters with police. Policing \& Society, 16, 99-126. doi:10.1080/10439460600662098

Skogan, W. G. (2009). Concern about crime and confidence in the police: Reassurance or accountability? Police Quarterly, 12, 301-317. doi:10.1177/1098611109339893

Tyler, T. R. (2006). Why people obey the law. Princeton, NJ: Princeton University Press.

Tyler, T. R., \& Huo, Y. J. (2002). Trust in the law: Encouraging public cooperation with the police and courts. New York: Russel Sage.

Weitzer, R. \& Tuch, S. A. (2005). Determinants of public satisfaction with the police. Police Quarterly, 8, 279-296. doi: $10.1177 / 1098611104271106$

Whalen, M. R., \& Zimmerman, D. H. (1987). Sequential and institutional contexts in calls for help. Social Psychology Quarterly, 50, 172-185. doi: $10.2307 / 2786750$

Whalen, M. R., \& Zimmerman, D. H. (1990). Describing trouble: Practical epistemology in citizen calls to the police. Language in Society, 19, 465-492. doi:10.1017/S0047404500014779

Zimmerman, D. H. (1992). The interactional organization of calls for emergency assistance. In P. Drew, \& J. Heritage (Eds.), Talk at work. Interaction in institutional settings (pp. 418-469). Cambridge: Cambridge University Press. 